\title{
Beslan 2004
}

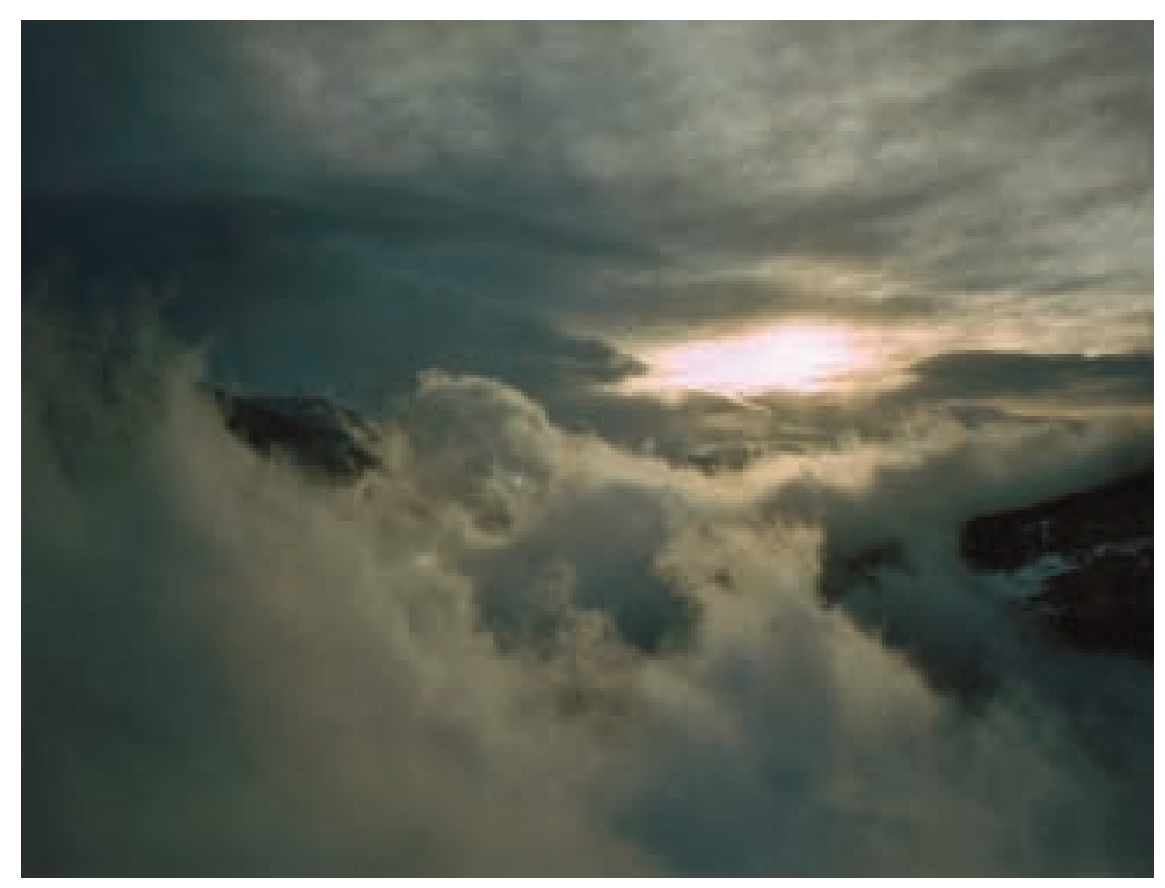

Il drappello di Satana

entra nella scuola

con mille martiri

e mille madri annientate.

«A morte gli ostaggi»

scandiscono le corde

dei cuori infernali,

perché Satana odia.

Giungono ordini

alla platea dei martiri:

«morire di sete, di fame,

di terrore e prima

buttar dalla finestra morti

padre, madre, bambini

e le sorelle violentate

nel mucchio».

Maria di Nazaret,

occhi di cielo,

anche tu qui,

a raccogliere a pezzi

il dolore delle mamme di Beslan, nell'ora di un Golgata nuovo,

tragico mistero del mondo.

Dr. Sergio Marengo, 6644 Orselina 